\title{
Proximate Composition and In-vitro Starch/Protein Digestibility of Bambara Groundnut Flour Fermented with Lactic Acid Bacteria (LAB)- Consortium Isolated from Cereals
}

\author{
Alloysius Chibuike Ogodo ${ }^{1 *}$, Ositadinma Chinyere Ugbogu ${ }^{2}$, Reginald Azu Onyeagba ${ }^{2}$ and Hope Chukwuemeka Okereke ${ }^{2}$ \\ ${ }^{1}$ Department of Microbiology, Faculty of Pure and Applied Sciences, Federal University Wukari, P.M.B. 1020, Wukari, Taraba State, Nigeria \\ ${ }^{2}$ Department of Microbiology, Faculty of Biological and Physical Sciences, Abia State University Uturu, P.M.B. 2000, Uturu, Abia State, Nigeria \\ "Corresponding author: Alloysius Chibuike Ogodo, Department of Microbiology, Faculty of Pure and Applied Sciences, Federal University Wukari, P.M.B. 1020, Wukari, \\ Taraba State, Nigeria, Tel: +234-806-666-3831; E-mail: ogodoac@fuwukari.edu.ng
}

Received date: December 06, 2017; Accepted date: December 20, 2017; Published date: January 05, 2018

Copyright: (c) 2018 Ogodo et al. This is an open-access article distributed under the terms of the Creative Commons Attribution License, which permits unrestricted use, distribution, and reproduction in any medium, provided the original author and source are credited.

\begin{abstract}
The effect of lactic acid bacteria (LAB) consortium fermentation on the proximate and in-vitro starch and protein digestibility of bambara groundnut flour was evaluated. Bambara groundnuts were processed into flour and fermented with LAB consortium previously isolated from maize (Lactobacillus plantarum WCFS1+Lactobacillus rhamnosus GG, ATCC53/03+Lactobacillus nantensis LP33+Lactobacillus fermentum CIP102980+Lactobacillus reuteri DSM 20016) and from sorghum (Pediococcus acidilactici DSM 20284+Lactobacillus fermentum CIP102980+Lactobacillus brevis ATCC14869+Lactobacillus nantensis LP33+Lactobacillus plantarum WCFS1). The sample was also fermented naturally for comparison. The results showed significant $(p<0.05)$ increase in the moisture, ash and protein contents of the bambara groundnut flour as fermentation time increased. The lipid and crude fibre contents decreased significantly $(p<0.05)$ with the increasing fermentation time in all the samples. The carbohydrate content decreased gradually from $50.66 \pm 0.23 \%$ to $44.96 \pm 0.10 \%$. The in-vitro starch digestibility increased significantly $(p<0.05)$ with increasing fermentation periods from $42.48 \pm 0.01 \% 50.36 \pm 0.02 \%$. The in-vitro protein digestibility increased significantly $(p<0.05)$ from $68.70 \pm 1.73 \%$ to $85.24 \pm 1.21 \%$. There was gradual increase in the bacteria load of the sample as fermentation time increased. However, fungal growth was only observed in natural fermentation. The occurrence of the isolates showed that the starter organisms were the only organisms isolated from the consortia fermentation set up while the natural fermentation have mixed microbial growth. This study has shown the effectiveness of LAB-consortium fermentation in improving the nutritional quality and the in-vitro starch and protein digestibility of flours from bambara groundnut.
\end{abstract}

Keywords: Lactic acid bacteria; Proximate composition; Fermentation; In-vitro starch/protein digestibility

\section{Introduction}

Legumes such as bambara groundnut, lima beans, cowpea, soybeans etc. play important role in the diets of many people in Africa and Asia and serve as major sources of protein, calories, vitamins and minerals [1]. However, legumes are usually rich in anti-nutritional factors associated with fibre that reduce mineral bioavailability. This has been the hindrance to their effective utilization [2,3]. Bambara groundnut (Voandzeia subterranean (L.) thousars) is a crop that is indigenous to Africa. It belongs to the Leguminosae, subfamily Papilionodease. There are two botanical varieties, namely, $V$. subterranean var spontanea which includes wild varieties and $V$. subterranean var subterranean which includes cultivated varieties [4]. Reports indicated that bambara groundnut has the potential to improve malnutrition and boost food availability. The seed makes a complete food, as it contains sufficient quantities of protein, carbohydrate and fat. Bambara groundnut seeds contain $63 \%$ carbohydrate, $19 \%$ protein and $6.5 \%$ oil; high proportion of lysine $(6.6 \%)$, methionine $(1.3 \%)$ and micronutrients. The gross energy is greater than that of cowpea, lentils (Lens esculenta) and pigeonpea (Cajanus cajan) [5-7].

Bambara groundnut is a good source of fibre, calcium, iron and potassium. The red seed could be useful in areas where iron deficiency is a problem. Bambara groundnut has the potential to provide a balanced diet in areas where animal protein is scarce or expensive and where the cultivation of other legumes is at risk due to low rainfall. Moreover, bambara groundnut compares favourably in nutritional attributes with cowpea, faba beans, chicken pea etc. Its protein content is higher in the essential amino acids particularly methionine when compared with other legumes $[6,8]$. Bambara groundnut oil is made of the unsaturated fatty acids, palmitoleic, oleic and caprylic acids required by the human body. These fatty acids are used to produce hormone-like substance that regulates a wide range of functions including blood pressure, blood clotting, blood lipid-level and inflammation response to injury infections $[9,10]$.

Lactic acid fermentation by LAB increases food palatability and improves the quality of food by increasing the availability of proteins and vitamins [11]. Furthermore, LAB confers preservative and detoxifying effects on food as well. When used regularly, LAB fermented foods boost the immune system and strengthen the body in the fight against pathogenic bacterial infections. Thus, lactic acid fermentation is not only of economic importance, it also promotes human health $[11,12]$.

The nutritional composition of legumes such as bambara groundnut can be improved using several methods such as cooking, toasting, salt treatment, soaking, fermentation etc. [13]. However the use of consortium of lactic acid bacteria as starter culture to improve to improve Bambara groundnut flour is not readily available in literature. 
Citation: Ogodo AC, Ugbogu OC, Onyeagba RA, Okereke HC (2018) Proximate Composition and In-vitro Starch/Protein Digestibility of Bambara Groundnut Flour Fermented with Lactic Acid Bacteria (LAB)-Consortium Isolated from Cereals. Ferment Technol 7: 148. doi: $10.4172 / 2167-7972.1000148$

Page 2 of 9

Hence, the objective of this present study was to ascertain the effect of $\mathrm{LAB}$ consortium fermentation on the proximate composition and invitro starch/protein digestibility of bambara groundnut and compare them with natural fermentation.

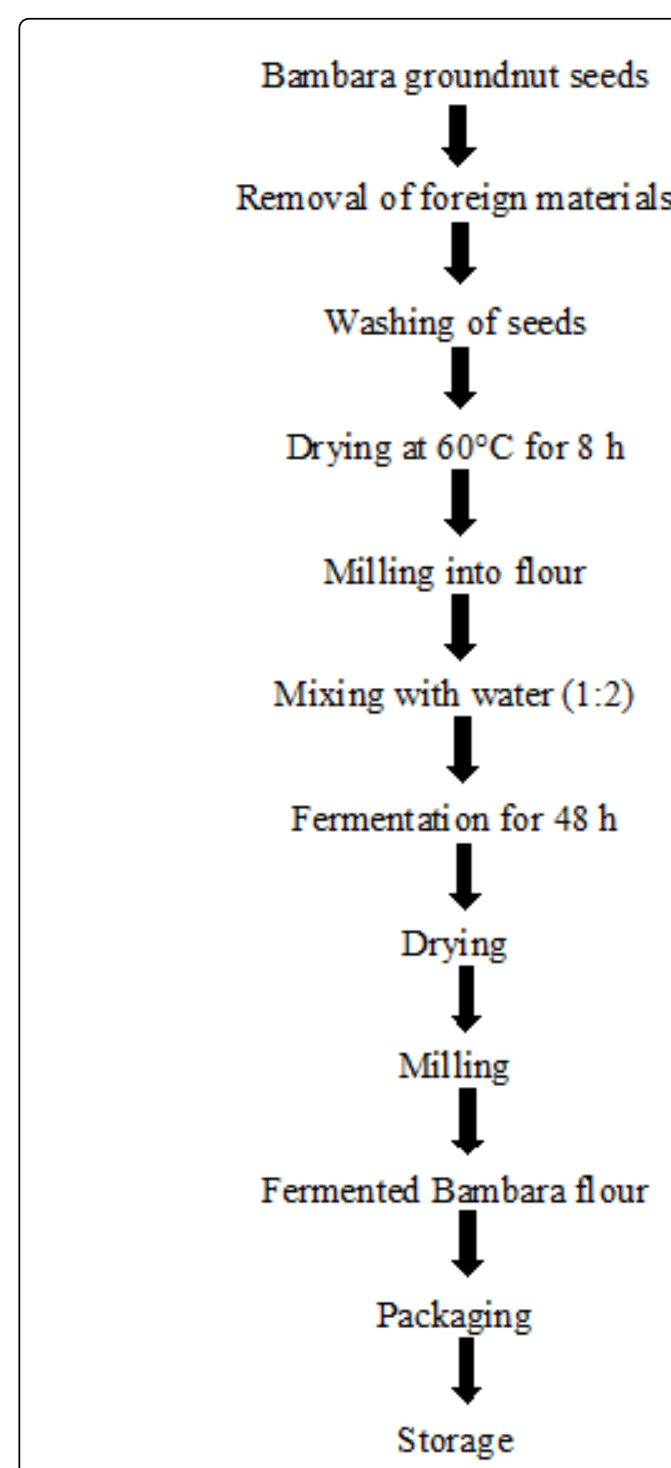

Figure 1: Process flow chart for the production of fermented Bambara groundnut flour.

\section{Materials and Methods}

\section{Source of materials}

Cream coloured Bambara groundnut (Voandzeia subterranean L) was obtained from Mushin market, Lagos State, Nigeria and transported to the laboratory in a clean polythene bags for analysis at Federal Institute of Industrial Research Oshodi (FIIRO). LAB ( $L b$. plantarum WCFS1, Lb. rhamnosus GG, ATCC 53/03, and Lb. reuteri DSM 20016, P. acidilactici DSM 20284, Lb. fermentum CIP 102980, Lb. brevis ATCC 14869, Lb. nantensis LP33) used were previously isolated from fermenting maize and sorghum. All the chemicals used were of analytical grade (AR).

\section{Choice of inoculum}

The consortia of the $\mathrm{LAB}$ were selected based on their tolerance to acid, tolerance to salt, lowering of $\mathrm{pH}$ in a fermentation broth, level of acid production during fermentation and growth on nutrient depleted medium after prefermentation studies as well as their reported benefits in food fermentation [14].

\section{Sample preparation}

The raw grains of Bambara groundnut were freed of foreign materials, washed with clean tap water and rinsed with distilled water. The samples were dried with hot air oven (GL, England) at $60^{\circ} \mathrm{C}$ for 8 $\mathrm{h}$. The dried samples were milled into powder using milling machine disinfected with $70 \%$ ethanol and stored in clean air tight containers at $4^{\circ} \mathrm{C}$ for further use [15].

\section{Inoculum preparation}

A combination of five lactic acid bacteria earlier isolated from each of fermenting maize ( $L b$. plantarum WCFS1, Lb. rhamnosus GG, ATCC 53/03, $L b$. nantensis LP33, $L b$. fermentum CIP 102980, and $L b$. reuteri DSM 20016) and fermenting sorghum ( $P$. acidilactici DSM 20284, Lb. fermentum CIP 102980, Lb. brevis ATCC 14869, Lb. nantensis LP33, and $L b$. plantarum WCFS1) for consortium from maize and sorghum respectively were grown in a $250 \mathrm{~mL}$ conical flask containing $210 \mathrm{~mL}$ MRS broth. These were incubated for $48 \mathrm{~h}$ in an orbital shaker incubator (REMI/396LAG) at $37^{\circ} \mathrm{C}$ for the inoculum to build-up. The inocula were harvested by centrifugation at $5000 \mathrm{rpm}$ for 10 min and maintained in fresh MRS broth before fermentation. The cells harvested were washed to free them from any form of media by centrifugation at $5000 \mathrm{rpm}$ for $10 \mathrm{~min}$ using sterile distilled water. The washed cells were diluted using sterile distilled water to obtain 0.5 McFarland standard [16].

\section{Fermentation of Bambara groundnut flours}

Fermentation was carried out based on the method described by Singh et al. [15] with slight modification. Each of the bambara groundnut sample was mixed with sterile distilled water $(1: 2 \mathrm{w} / \mathrm{v})$. Exactly $500 \mathrm{~g}$ of the legume flour was mixed with $1000 \mathrm{~mL}$ of distilled water in sterile fermentation containers with the addition of $0.5 \mathrm{~g} / \mathrm{L}$ potassium sorbate to inhibit fungal growth and other contaminating organisms (verified by none existence of growth on plate count agar after 18-24 h of incubation). The mixture was inoculated with $10 \mathrm{~mL}$ of $10^{8}$ cells $/ \mathrm{mL}$ (measured using McFarland standard) of the mixture of the LAB suspension and allowed to ferment. Samples were taken at 12 $\mathrm{h}$ intervals of $0,12,24,36$ and $48 \mathrm{~h}$ for analysis. The various samples were also allowed to ferment naturally as control trial for spontaneous fermentation (Figure 1).

\section{Proximate analysis}

The moisture, Ash, protein, fibre and carbohydrate contents were determined according to AOAC method [17]. The lipid composition was determined using Soxhlet extraction method as described by Ojiako and Akubugwo [18]. 
Citation: Ogodo AC, Ugbogu OC, Onyeagba RA, Okereke HC (2018) Proximate Composition and In-vitro Starch/Protein Digestibility of Bambara Groundnut Flour Fermented with Lactic Acid Bacteria (LAB)-Consortium Isolated from Cereals. Ferment Technol 7: 148. doi: $10.4172 / 2167-7972.1000148$

Page 3 of 9

\section{In-vitro starch and protein digestibility}

In-vitro starch digestibility (IVSD) was determined according to the method described by Singh et al. [15]. Exactly $50 \mathrm{mg}$ each of the samples was mixed with $1 \mathrm{~mL}$ of $0.2 \mathrm{M}$ phosphate buffer ( $\mathrm{pH}$ 6.9). 0.5 $\mathrm{mL}$ of pancreatic alpha amylase $(100 \mathrm{unit} / \mathrm{mg})$ was added to the sample and incubated at $37^{\circ} \mathrm{C}$ for $2 \mathrm{~h}$. After incubation, $2 \mathrm{~mL}$ of 3,5 -DNS reagent was added immediately. The mixture was heated for 5-15 min in a boiling water bath. After heating, $1.0 \mathrm{~mL}$ of $40 \% \mathrm{~K}-\mathrm{Na}$ Tartarate solution was added in the test tubes and allowed to cool at room temperature $\left(25^{\circ} \mathrm{C}\right)$. The solution was made up to $25 \mathrm{~mL}$ with distilled water and filtered prior to measurement of the absorbance at $550 \mathrm{~nm}$. A blank was run simultaneously. A standard curve was prepared using maltose. Values were expressed as $\mathrm{mg}$ maltose released per $100 \mathrm{mg}$ of sample.

The in-vitro protein digestibility (IVPD) of the samples was determined by enzymatic method of Monjula and Jhon [19]. $1 \mathrm{~g}$ each of the samples was taken in triplicate and digested with $1 \mathrm{mg}$ pepsin in $15 \mathrm{~mL}$ of $0.1 \mathrm{M} \mathrm{HCl}$ at $37^{\circ} \mathrm{C}$ for $2 \mathrm{~h}$. The reaction was stopped by the addition of $15 \mathrm{~m} \mathrm{10 \%}$ trichloro-acetic acid (TCA). The mixture was filtered quantitatively through Whatman No. 1 filter paper. The TCA soluble fraction was assayed for nitrogen using the micro-kjeldahl method. Protein digestibility of the sample was calculated by the following formula:

$$
\begin{aligned}
& \text { Protein Digestibility (\%) }= \\
& \frac{N \text { in Supernatant }- \text { Blank } N}{N \text { in Sample }} \times 100
\end{aligned}
$$

\section{Enumeration, isolation and identification of microorganisms}

At the intervals of $0,8,24$ and $48 \mathrm{~h}$, exactly $1.0 \mathrm{~g}$ (wet weight) of the fermenting flours were homogenized in $9.0 \mathrm{~mL}$ sterile peptone water for $30 \mathrm{~s}$. A 1:10 serial dilution of the various mixtures were made and $0.1 \mathrm{~mL}$ from 10-6 dilution was inoculated on the respective media, nutrient agar, plate count agar (PCA), MacConkey agar (MA), deMan
Rogosa \& Sharpe agar (MRS) and Sabroud dextrose agar (SDA), for the determination of total heterotrophic count, coliform count, lactic acid bacterial and fungal counts respectively. The cultured plates were incubated at room temperature for $24 \mathrm{~h}$ and then counted using colony counter. Subsequent cultures were made on fresh sterile, nutrient agar plates for pure cultures. The pure cultures of bacteria obtained were identified based on colonial characteristics, Microscopy, Biochemical reactions and Carbohydrate utilization [20,21]. The carbohydrate fermentation profiles of the LAB isolates were investigated using API $50 \mathrm{CHL}$ medium according to manufacturer's instructions (API System, Bio-Merieux, France). The identification of the bacterial strain was subsequently performed using the apiweb identification software and with reference to Bergey's Manual of Determinative Bacteriology [22]. The fungi were identified on the basis of their cultural characteristics, microscopy and with reference to the methods described by Bernett et al. [23].

\section{Results}

\section{Proximate composition}

The moisture content of bambara groundnut increased with increasing fermentation time and ranged from $8.90 \pm 0.03 \%$ in unfermented sample to $10.34 \pm 0.05 \%$ in LAB-consortium from sorghum fermented sample (Figure 2). The effect of fermentation on the ash content of the fermented and unfermented bambara flours under study showed a progressive increase as the fermentation time increased from $3.38 \pm 0.04 \%$ (unfermented sample) to $4.20 \pm 0.00 \%$ (Fermented with LAB-consortium from maize) (Figure 3 ). The variations in the ash content of the bambara sample do not differ significantly $(\mathrm{p}>0.05)$ when compared with LAB-consortium from maize and LAB-consortium from sorghum fermented samples. However, the variations differ significantly $(\mathrm{p}<0.05)$ when compared

\begin{tabular}{|c|c|c|c|c|c|c|c|c|c|c|c|c|}
\hline \multirow[t]{2}{*}{ FT } & \multicolumn{3}{|c|}{ PCA (TVC) } & \multicolumn{3}{|c|}{ MRS (TLBC) } & \multicolumn{3}{|c|}{ MCA (TCC) } & \multicolumn{3}{|c|}{ SDA (TFC) } \\
\hline & $\mathrm{NF}$ & MF & SF & NF & MF & SF & $\mathrm{NF}$ & MF & SF & $\mathrm{NF}$ & MF & SF \\
\hline 0 & $1.20 \times 10^{9}$ & $5.44 \times 10^{8}$ & $4.98 \times 10^{8}$ & $4.28 \times 10^{6}$ & $4.86 \times 10^{8}$ & $4.02 \times 10^{8}$ & 0.00 & 0.00 & 0.00 & $2.40 \times 10^{3}$ & 0.00 & 0.00 \\
\hline 12 & $1.80 \times 10^{9}$ & $6.80 \times 10^{8}$ & $6.92 \times 10^{8}$ & $4.66 \times 10^{6}$ & $6.44 \times 10^{8}$ & $6.71 \times 10^{8}$ & 0.00 & 0.00 & 0.00 & $2.81 \times 10^{3}$ & 0.00 & 0.00 \\
\hline 24 & $2.00 \times 10^{9}$ & $7.42 \times 10^{8}$ & $8.00 \times 10^{8}$ & $5.33 \times 10^{6}$ & $7.38 \times 10^{8}$ & $7.77 \times 10^{8}$ & 0.00 & 0.00 & 0.00 & $3.20 \times 10^{3}$ & 0.00 & 0.00 \\
\hline 36 & $2.18 \times 10^{9}$ & $8.80 \times 10^{8}$ & $9.20 \times 10^{8}$ & $5.41 \times 10^{6}$ & $8.12 \times 10^{8}$ & $8.66 \times 10^{8}$ & 0.00 & 0.00 & 0.00 & $3.52 \times 10^{3}$ & 0.00 & 0.00 \\
\hline 48 & $2.33 \times 10^{9}$ & $8.40 \times 10^{8}$ & $8.60 \times 10^{8}$ & $5.72 \times 10^{6}$ & $8.02 \times 10^{8}$ & $8.42 \times 10^{8}$ & 0.00 & 0.00 & 0.00 & $3.72 \times 10^{3}$ & $0.30 \times 10^{1}$ & $0.50 \times 10^{1}$ \\
\hline
\end{tabular}
with the unfermented sample at $36 \mathrm{~h}$ and $48 \mathrm{~h}$ respectively.

Table 1: Effect of fermentation on the microbial load (CFU/g) of the Bambara groundnut flour after natural (N), LAB consortium from maize (M) and LAB-consortium from sorghum (S) fermentation on different media. Plate count agar (PCA) was used for total viable count (TVC), de Man Rogosa and Sharpe agar (MRS) used for LAB count (TLBC), MacConkey agar (MCA) used for total coliform count (TCC) while Sabroud Dextrose agar (SDA) was used for total fungal count.

The percentage lipid content of bambara groundnut which showed a significant $(\mathrm{p}<0.05)$ decrease with increasing fermentation periods was presented in Figure 4. It ranged from $7.14 \pm 0.03 \%(48 \mathrm{~h}$ LABconsortium from sorghum fermented sample) to $8.20 \pm 0.03 \%$ (unfermented sample). The difference in the fat content of the fermented and unfermented samples differ significantly $(\mathrm{p}<0.05)$. However, the variations in the fat content of the samples do not differ significantly $(p>0.05)$ when compared between naturally fermented samples and LAB-consortium from maize fermented samples. The protein content of bambara also increased with increasing 
Citation: Ogodo AC, Ugbogu OC, Onyeagba RA, Okereke HC (2018) Proximate Composition and In-vitro Starch/Protein Digestibility of Bambara Groundnut Flour Fermented with Lactic Acid Bacteria (LAB)-Consortium Isolated from Cereals. Ferment Technol 7: 148. doi: $10.4172 / 2167-7972.1000148$

Page 4 of 9

fermentation time from $26.69 \pm 0.58 \%$ in the unfermented sample to $32.91 \pm 0.14 \%$ in LAB-consortium from sorghum fermented sample (Figure 5).

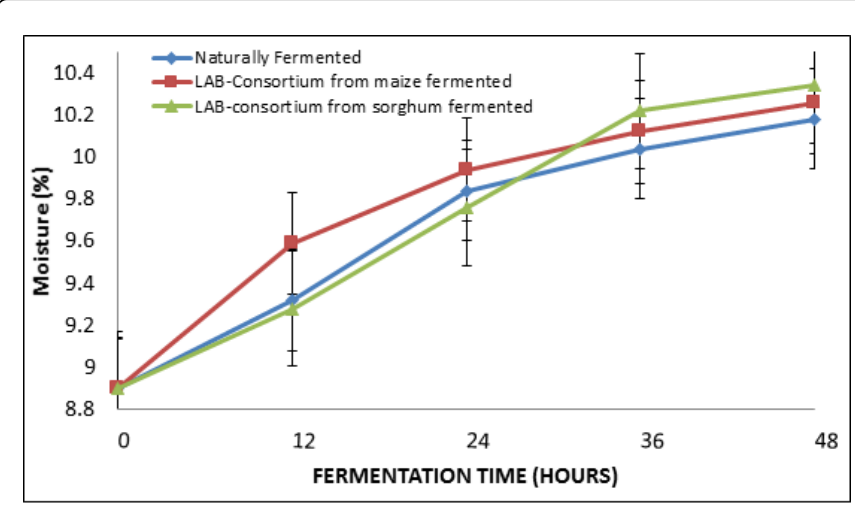

Figure 2: Moisture content of LAB fermented bambara groundnut flours at different time intervals. Each point represent the mean of three independent experiments and error bars indicate \pm SE.

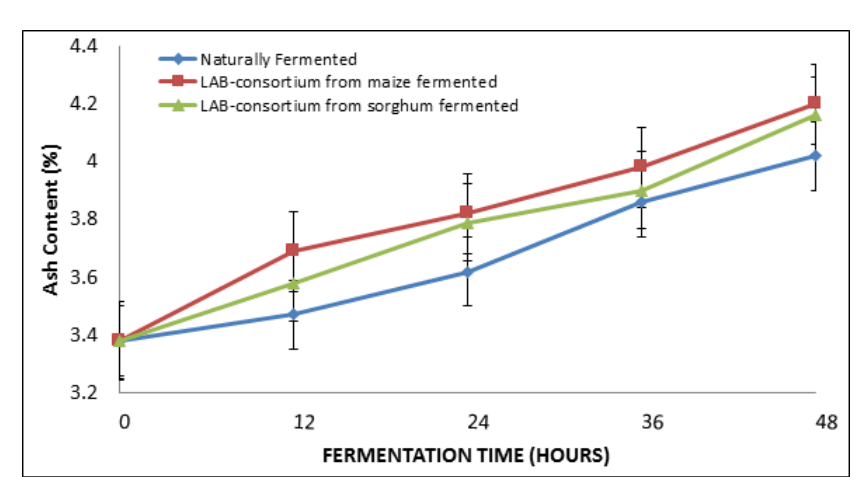

Figure 3: Ash content of LAB fermented bambara groundnut flours at different time intervals. Each point represent the mean of three independent experiments and error bars indicate \pm SE.

The fibre content of bambara groundnut decreased with increasing fermentation time from $2.02 \pm 0.05 \%$ in the unfermented sample to $0.44 \pm 0.12 \%$ in the sample fermented with LAB-consortium from sorghum (Figure 6). There was significant difference $(\mathrm{p}<0.05)$ between the fibre content of fermented and unfermented sample and when compared across the periods of fermentation between naturally fermented, fermented with LAB consortium from maize and sorghum. Similarly, the carbohydrate composition of bambara groundnut decreased with increasing fermentation time. It decreased from $50.66 \pm$ $0.23 \%$ to $44.96 \pm 0.10 \%$ (Figure 7 ).

\section{In-vitro starch digestibility}

The in-vitro starch digestibility increased from the initial value of $42.48 \pm 0.01 \%$ to $48.69 \pm 0.01 \%, 42.48 \pm 0.01 \%$ to $51.72 \pm 0.02 \%$ and $42.48 \pm 0.02 \%$ to $50.36 \pm 0.02 \%$ in naturally fermented, LABconsortium from maize fermented and LAB-consortium from sorghum fermented samples respectively. The changes in the in-vitro starch digestibility differed significantly $(\mathrm{p}<0.05)$ at $24 \mathrm{~h}, 36 \mathrm{~h}$ and $48 \mathrm{~h}$ in LAB-consortium from maize and sorghum fermented samples and at $48 \mathrm{~h}$ in naturally fermented sample when compared with the unfermented sample respectively. There was no significant difference $(p>0.05)$ in the in-vitro starch digestibility between the naturally fermented and the LAB-consortium from maize and sorghum fermented sample (Figure 8).

\section{In-vitro protein digestibility}

The effect of fermentation on the percentage in-vitro protein digestibility of the bambara groundnut flour samples under study was presented in figure 9. The in-vitro protein digestibility increased from the initial value of $68.70 \pm 1.73 \%$ to $80.24 \pm 1.12 \%, 68.70 \pm 1.73 \%$ to $86.68 \pm 1.36 \%$ and $68.70 \pm 1.73 \%$ to $85.24 \pm 1.21 \%$ in naturally fermented, LAB-consortium from maize fermented and LABconsortium from sorghum fermented samples respectively. The changes in the in-vitro protein digestibility differed significantly $(\mathrm{p}<0.05)$ at $24 \mathrm{~h}, 36 \mathrm{~h}$ and $48 \mathrm{~h}$ in fermented sample when compared with the unfermented sample. There was no significant difference $(p>0.05)$ in the in-vitro protein digestibility between the naturally fermented and the LAB-consortium from maize and sorghum fermented samples.

\section{Microbiological analysis}

The total number of microorganisms (TVC) in the fermenting Bambara groundnut sample under study increased gradually with increasing fermentation periods. It ranged from $4.98 \times 10^{8} \mathrm{CFU} / \mathrm{g}(0 \mathrm{~h}$ LAB-consortium from sorghum fermented sample) to $2.33 \times 10^{9}$ CFU/g (48 h naturally fermented sample). The total LAB count (TLBC) increased consistently to $36 \mathrm{~h}$ of fermentation and showed a slight decrease at $48 \mathrm{~h}$ of fermentation in all the fermentation set-ups and ranged from $4.86 \times 10^{6} \mathrm{CFU} / \mathrm{g}$ ( $0 \mathrm{~h}$ naturally fermented sample) to $8.66 \times 10^{8} \mathrm{CFU} / \mathrm{g}$ (36 h LAB-consortium from sorghum fermented sample). No coliform was observed in all the fermentation set-ups. The total fungal count showed gradual increase in natural fermentation (Table 1).

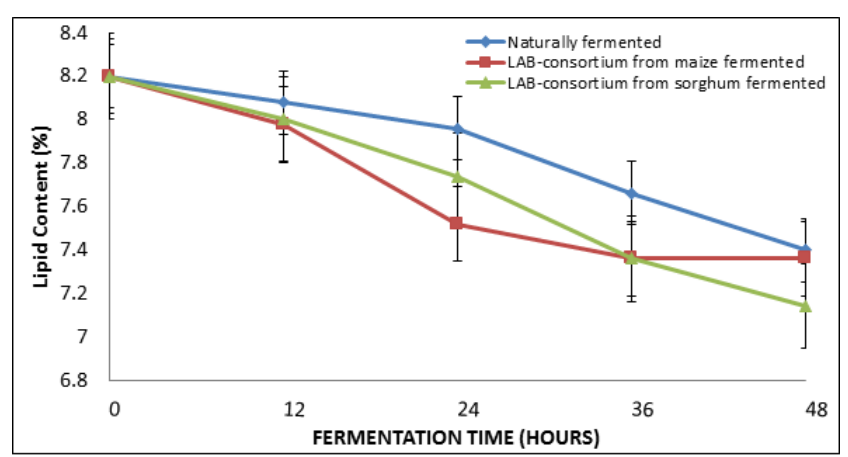

Figure 4: Lipid content of LAB fermented bambara groundnut flours at different time intervals. Each point represent the mean of three independent experiments and error bars indicate \pm SE.

Table 2 presented the occurrence of various bacteria, yeast and mould in the fermented product. The organisms isolated include $L b$. fermentum, $L b$. plantarum, $L b$. natensis, $L b$. reuteri, $L b$. rhamnosus, $L b$. brevis, Lb. lactis, Lb. bulgaricus, Lb. brevis, P. acidilactici, Leuconoscoc mesenteroides, Candida utilis and Rhizopus species. $L b$. fermentum, and $L b$. plantarum were isolated from all the samples and 
Citation: Ogodo AC, Ugbogu OC, Onyeagba RA, Okereke HC (2018) Proximate Composition and In-vitro Starch/Protein Digestibility of Bambara Groundnut Flour Fermented with Lactic Acid Bacteria (LAB)-Consortium Isolated from Cereals. Ferment Technol 7: 148. doi: $10.4172 / 2167-7972.1000148$

Page 5 of 9

from all the fermentation set ups. Lb. natensis was only isolated from the LAB-consortia fermented samples. L. reuteri was isolated from samples fermented with LAB-consortium from maize and in naturally fermented sample. L. bervis was only isolated from samples fermented with LAB-consortium from sorghum while $L$. lactis and $L$. mesenteroides were isolated from the naturally fermented sample. $C$. utilis and Rhizopus species were only isolated from naturally fermented sample.

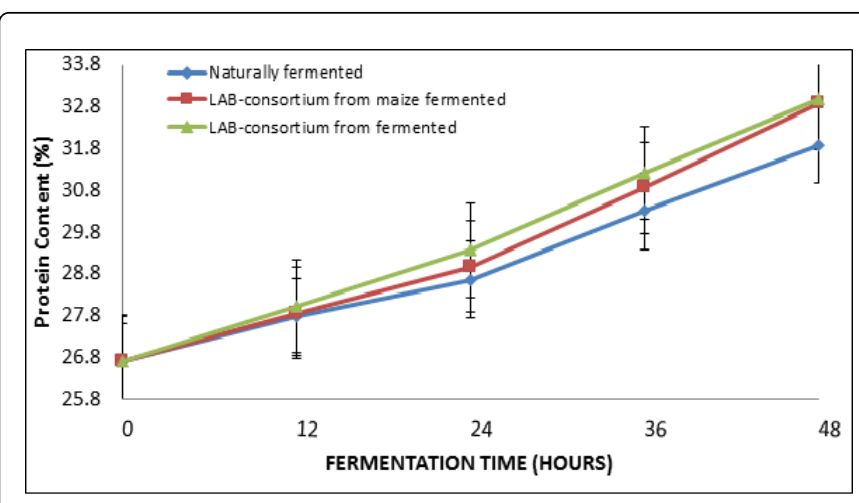

Figure 5: Protein content of LAB fermented bambara groundnut flours at different time intervals. Each point represent the mean of three independent experiments and error bars indicate \pm SE.

\section{Discussion}

\section{Proximate composition}

The changes in the moisture content of bambara groundnut flour in the present study differ significantly $(\mathrm{P}<0.05)$ when compared between naturally fermented, $\mathrm{LAB}$-consortium from maize and LABconsortium from sorghum fermented samples at each successive fermentation time interval and in between the time interval of each fermentation set-up except between $36 \mathrm{~h}$ and $48 \mathrm{~h}$ fermented samples. There was also significant different $(\mathrm{P}<0.05)$ between the fermented samples and the unfermented sample at each $12 \mathrm{~h}$ intervals. There was also significant different $(\mathrm{P}<0.05)$ between the fermented samples and the unfermented sample at each $12 \mathrm{~h}$ intervals. The results agreed with the report of Bamishaiye et al. [7] who reported 9.7\% for cream coloured bambara groundnut. The present study also corresponded with the reports for other legumes such as cowpea (9.2 $\pm 0.10 \%)$ [24], pigeon pea (10.20\%-13.24\%) [25]. The increase in moisture content with increasing fermentation time could be as a result of the addition of water to mix the substrate before fermentation. However, the moisture content reported in the present study is low which is desirable as low moisture discourages the growth of spoilage microorganisms and enhances the shelf-life of the product [26].

The ash content of bambara groundnut in the present study increased significantly $(\mathrm{p}<0.05)$ with increasing fermentation period. There were significant differences $(p<0.05)$ for values obtained at each successive time interval when compared with the unfermented sample. Also, there were significant differences at each time interval when compared with the preceding fermentation period in all the fermentation set-ups. The comparison between the naturally, LABconsortium from maize and sorghum fermented samples showed that there were significant differences $(\mathrm{p}<0.05)$. The highest ash content was found in LAB-consortium from maize fermented sample $(4.20 \pm$
$0.00 \%)$, followed by LAB-consortium from sorghum fermented sample $(4.16 \pm 0.04 \%)$ and naturally fermented $(4.01 \pm 0.02 \%)$ while the unfermented sample was the least $(3.80 \pm 0.04 \%)$. These values are lower when compared with $10.40 \%$ reported by Midala et al. [27]. Adebowale and Maliki [25] reported increase in ash content with increasing fermentation period in the range of $4.61-5.52 \%$ for pigeon pea which is consistent with the present study. On the other hand, the result obtained for bambara groundnut in the present study agreed with the report of Olanipekun et al. [10] who reported increase in ash content with increasing fermentation time in bambara nut in the range of 3.75-4.41 but higher than the report of Bamishaiye et al. [7] and Mazahib et al. [28] that reported 2.5 and $3.25 \%$ respectively and slightly lower than the results for jack beans $(6.51 \pm 0.07 \%)$, pigeon pea $(4.58 \pm 0.40 \%)$ and cowpea $(4.73 \pm 0.3 \%)$ as reported by Olalekan and Bosede [24]. Ntuli et al. [29] reported that ash content increment leads to increase in mineral content and an indication of the level of mineral composition of the substrates. In the present study, the ash content increased with increasing time of fermentation. The increment was highest in sample fermented with LAB-consortium from maize, followed by sample fermented with LAB-consortium from sorghum and then naturally fermented sample. This demonstrated the effectiveness of the consortia in improving the mineral composition of the substrates.

\begin{tabular}{|l|l|l|l|l|}
\hline \multirow{2}{*}{ S/N } & \multirow{2}{*}{ Organisms Isolated } & \multicolumn{3}{|c|}{ Bambara } \\
\cline { 3 - 6 } & & NF & MF & SF \\
\hline 1. & Lactobacillus fermentum & + & + & + \\
\hline 2. & Lactobacillus plantarum & + & + & + \\
\hline 3. & Lactobacillus nantensis & - & + & + \\
\hline 4. & Lactobacillus reuteri & + & + & - \\
\hline 5. & Lactobacillus rhamnosus & - & + & - \\
\hline 6. & Lactobacillus brevis & - & - & + \\
\hline 7. & Lactococcus lactis & + & - & - \\
\hline 8. & Lactobacillus bulgaricus & + & - & - \\
\hline 9. & Pediococcus acidilactici & - & - & + \\
\hline 10. & Leuconostoc mesenteroides & + & - & - \\
\hline 12 & Candida utilis & + & - & - \\
\hline 13. & Rhizopus species & + & - & - \\
\hline$+:$ Present; - Absent & & & \\
\hline
\end{tabular}

Table 2: Occurrence of bacteria and fungi isolates in the fermented flour after natural $(\mathrm{N}), \mathrm{LAB}$ consortium from maize $(\mathrm{M})$ and LABconsortium from sorghum (S) fermentation.

In the present the fat composition of bambara groundnut decreased from $8.19 \pm 0.19 \%$ (unfermented sample) to $7.14 \pm 0.06 \%$ (48 h LABconsortium from sorghum fermented sample). Babalola and Giwa [30], reported $6.60 \%$ for pigeon pea which is similar to the present study and higher than the range $2.74-1.69 \%$ reported by Adebowale and Malik [25] for fermented bambara groundnut. The reduction could be due to hydrolysis of fat components into fatty acids and glycerol [31]. It could also be due to biochemical and physiological changes that occur 
Page 6 of 9

due to fermentation progresses that require energy and part of the lipid composition are used for this purpose [32-34]. This could also be attributed to the breakdown of fatty acids and glycerol by the fermenting lactic acid bacteria, which enhances aroma, taste and texture as reported by Ojokoh and Bello [35]. Reports indicate that high fat content triggers rancidity during storage, giving rise to off flavor $[29,36]$. Therefore fermentation with LAB consortium could serve as a means of reducing rancidity in samples. The present report has shown that LAB-consortia fermentation are more effective in fat content reduction than the naturally fermentation.

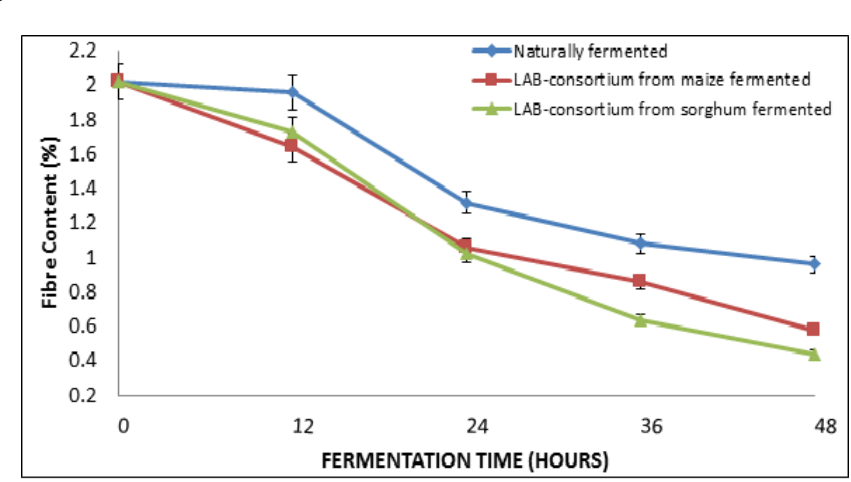

Figure 6: Fibre content of LAB fermented bambara groundnut flours at different time intervals. Each point represent the mean of three independent experiments and error bars indicate \pm SE.

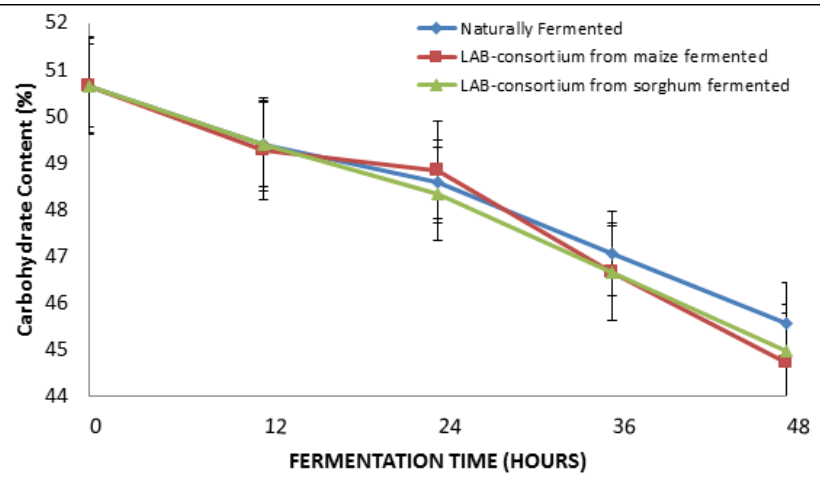

Figure 7: Carbohydrate content of LAB fermented bambara groundnut flours at different time intervals. Each point represent the mean of three independent experiments and error bars indicate \pm SE.

The protein content of bambara groundnut was observed to increase with fermentation time ranging from $26.69 \pm 0.58 \%$ in the unfermented sample to $32.91 \pm 0.14 \%$ in LAB-consortium from sorghum fermented sample. The observation in the present study is similar to the reports of Babalola and Giwa [30] and Ojokoh et al. [37]. The report is also similar to the range $21.8-23.9 \%$ reported by Adebowale and Maliki [25] for pigeon pea, although higher values were obtained in the present study. The increases in the protein contents of the sample with increasing fermentation time could be attributed to the increase in the number of the fermenting microorganisms during fermentation as reported by Ojokoh et al.
$[38,39]$. It can also be due to proteolytic enzymes produced by the fermenting $\mathrm{LAB}[40,41]$ or as a result of synthesis of protein by fermenting substrates which could have resulted to production of more amino acids [30]. The present report has also demonstrated that LAB consortium from sorghum and $\mathrm{LAB}$ consortium from maize are more effective in improving the protein content of the final product.

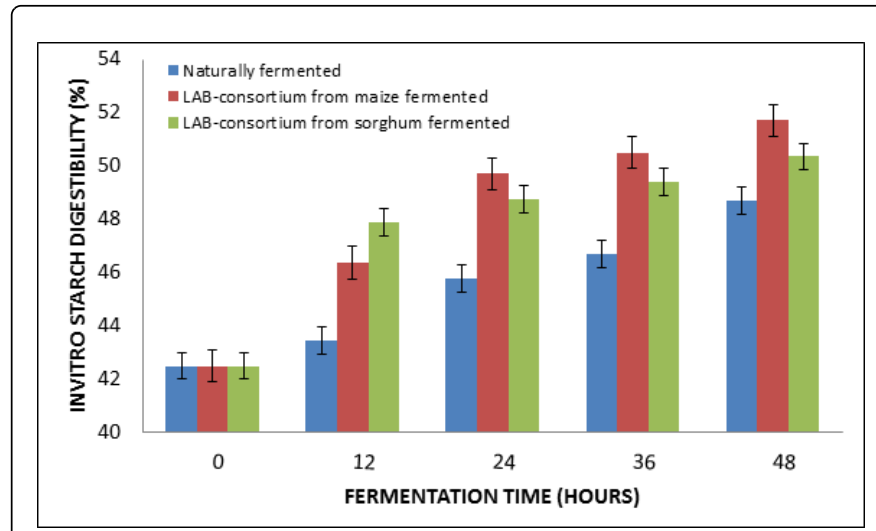

Figure 8: In-vitro starch digestibility of LAB fermented bambara groundnut flours at different time intervals. Each point represent the mean of three independent experiments and error bars indicate \pm SE.

The fibre content of bambara groundnut decreased with increasing fermentation time from $2.02 \pm 0.05 \%$ in the unfermented sample to $0.44 \pm 0.12 \%$ in the sample fermented with LAB-consortium from sorghum. There was significant difference $(p<0.05)$ between the fibre content of fermented and unfermented sample and when compared across the periods of fermentation between naturally fermented, fermented with LAB consortium from maize and sorghum. [30], reported decrease in fibre content of soybean as a result of fermentation which is in consistence with the present observation. However, the fibre content obtained for bambara groundnut in the present study is lower than the $6.34 \%$ reported by Babalola and Giwa [30]. The general decrease in the fibre composition could be due to the ability of the fermenting organisms (Lactic acid bacteria) to metabolize the fibre and enzymatically break it down during fermentation and utilize them as carbon source [35]. The present investigation has also shown the effectiveness of the LAB consortia from maize and sorghum in metabolizing the fibre more than natural fermentation.

There were significance differences $(\mathrm{p}<0.05)$ in the decrease in carbohydrate composition of Bambara groundnut flours at all interval of fermentation when compared with the unfermented in all fermentation set-ups. The decrease in carbohydrate content observed in the present study during fermentation could be due to hydrolyses of starch as a result of amylases produced by LAB into simple fermentable sugars. Roger et al. [42] reported that LAB from maize have strong amylolytic activity which is in consistent with the present investigation.

\section{In-vitro starch digestibility}

The percentage in-vitro starch digestibility (IVSD) of bambara groundnut samples under study showed a significant $(\mathrm{p}<0.05)$ increase as fermentation time increased. In all the samples, the changes in the in-vitro starch digestibility differed significantly $(\mathrm{p}<0.05)$ at $12 \mathrm{~h}, 24 \mathrm{~h}$, $36 \mathrm{~h}$ and $48 \mathrm{~h}$ of fermented samples when compared with the 
unfermented sample and when the LAB-consortia are compared with natural fermentation. However, there was no significant different $(p>0.05)$ in the in-vitro starch digestibility between the naturally fermented and the LAB-consortium from maize and sorghum fermented samples respectively. The present study agreed with the work of Singh et al. [15] who reported increase in the IVSD of sorghum, maize and millet with increasing fermentation time. The increase could be attributed to the role of fermentation in causing changes in the endosperm protein which makes starch more accessible to the digestive enzymes $[15,43]$.

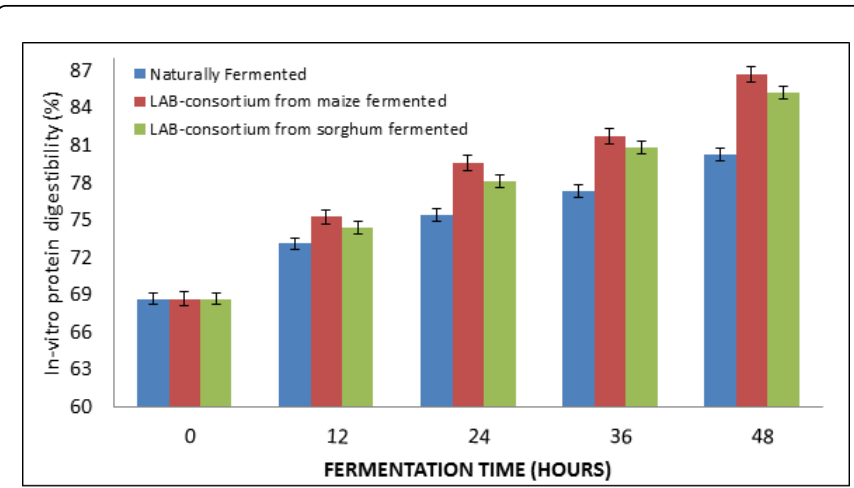

Figure 9: In-vitro protein digestibility of LAB fermented bambara groundnut flours at different time intervals. Each point represent the mean of three independent experiments and error bars indicate \pm SE.

\section{In-vitro protein digestibility}

In the present study, the effect of fermentation on the percentage invitro protein digestibility (IVPD) of bambara flour showed a significant $(\mathrm{p}<0.05)$ increase as fermentation time increased. Olianipekun et al. [3] reported a significant increase in protein digestibility of bambara groundnut flours after $0-72 \mathrm{~h}$ of fermentation using species of fungi. Also, Chen et al. [44] reported increase in IVPD of soybean meal fermented with a combination of Aspergillus and Lactobacillus from $87.50 \%$ to $92.23 \%$. Singh et al. [15] and Mohiedeen et al. [45] reported that fermentation improves the IVPD of maize, millet and sorghum. This could be as a result of the reduction in $\mathrm{pH}$ during fermentation which plays an important role in enhancing the proteolytic enzyme activity and in turn leads to the breakdown of proteins to smaller polypeptides which are easily digested as well as the production of proteolytic enzymes by the microflora which hydrolyze proteins and improve digestibility $[3,15]$.

In the present study, the highest starch/protein digestibility was observed in samples fermented with the LAB consortia while the naturally fermented and the unfermented samples were the lowest. This shows that LAB consortia fermentation is more effective in improving the IVSD and IVPD of the sample more than the naturally fermented and the unfermented sample.

\section{Microbiological analysis}

Fermentation caused an increase in the total viable which ranged from $4.98 \times 10^{8} \mathrm{CFU} / \mathrm{g}$ to $2.33 \times 10^{9} \mathrm{CFU} / \mathrm{g}$. The total LAB count (TLBC) increased consistently to $36 \mathrm{~h}$ of fermentation. No coliform was observed in all the fermentation set-ups. This could be attributed to the low $\mathrm{pH}$ values which inhibited the growth of coliforms [46]. Fungal growth occurred in naturally fermented sample and at $48 \mathrm{~h}$ of the consortia fermentation only. Ogunsakin et al. [47] reported increase in $\mathrm{LAB}$ and yeast population of sorghum during sourdough bread production which agreed with the present finding. This may be attributed to the fermentation conditions that tends to favour the growth of LAB [48].

The predominant organism isolated from the LAB consortia fermentation belong to the members of the starter organisms. This shows that the starter organisms were able to grow and created environment which did not allow other contaminating microorganisms to thrive. Also, the natural fermentation was predominated by $\mathrm{LAB}$, yeasts and moulds organisms representing the native microbiota of the substrate. Similar organisms has been reported by previous researchers with other substrates such as millet and soyabean blend flours [35] and ogi [49,50]. Also, Ojokoh et al. [41] reported that $\mathrm{LAB}$ is the predominant microorganism associated with the fermentation of pearl millet. Adegbehingbe and Maliki [26] isolated Lactobacillus fermentum, Lactobacillus plantarum, L. brevis, Bacillus subtilis, Saccharomyces cerevisiae, Rhizopus nigrificans and A. niger from sorghum co-fermented with lima beans seed. In the present study, Lactobacillus fermentum, and Lactobacillus plantarum were isolated from all the fermentation set ups. This is an indication of codominance of the facultative heterofermenter with other heterofermentative $\mathrm{CO}_{2}$ producers [51]. Also, the presence of Lactococcus lactis, Lactobacillus bulgaricus, Leuconostoc species, Candida utilis and Rhizopus species in the naturally fermented sample but absent in the consortia fermented samples showed that the starter organisms predominated the native LAB and fungi microbiota.

\section{Conclusion}

The proximate composition of bambara groundnut in the present study improved significantly $(\mathrm{p}<0.05)$ after natural, LAB-consortium from maize and LAB-consortium from sorghum fermentation. The invitro protein and starch digestibility of the samples also improved significantly $(\mathrm{p}<0.05)$ with increasing fermentation. The highest improvement was observed in the samples fermented with the LABconsortia in all the parameters analyzed. The LAB-consortium from maize and $\mathrm{LAB}$-consortium from sorghum fermented samples did not differ significantly $(p>0.05)$ in most of the parameters analyzed. This suggests that LAB consortium fermentation is an effective means of improving the nutritional qualities as well as the in-vitro starch/protein digestibility of Bambara groundnut flours more than natural fermentation. More so, the organisms encountered in the present study are mostly ones generally regarded as safe (GRAS) which is an indication of safety.

\section{Conflicts of Interest}

The authors have declared no conflict of interest.

\section{References}

1. Nkama I, Dagwanna FN, Ndahi WB (2001) Production, composition and consumer acceptability of weaning food from mixture of pearl millet, cowpea and groundnut. J Arid Agric 11: 165-169.

2. Dueñas M, Hernández T, Robredo S, Lamparski G, Estrella I, Muñoz R (2012) Bioactive phenolic compounds of soybean (Glycine max cv. Merit): Modifications by different microbiological fermentations. Pol J Food Nutr Sci 62: 241-250. 
Citation: Ogodo AC, Ugbogu OC, Onyeagba RA, Okereke HC (2018) Proximate Composition and In-vitro Starch/Protein Digestibility of Bambara Groundnut Flour Fermented with Lactic Acid Bacteria (LAB)-Consortium Isolated from Cereals. Ferment Technol 7: 148. doi: $10.4172 / 2167-7972.1000148$

Page 8 of 9

3. Olanipekun BF, Otunola ET, Oyelade OJ (2015) Effect of fermentation on antinutritional factors and in vitro protein digestibility of bambara nut (Voandzeia subterranean L.). Food Sci Qual Manag 39: 98-112.

4. Murevanhema YY (2012) Evaluation of bambara groundnuts (Vigna subterrenea (L.) Verdc.) milk fermented with lactic acid bacteria as a probiotic beverage. MSc. Thesis. Department of Food Technology Faculty of Applied Sciences Cape Peninsula University of Technology.

5. Mahala AGA, Mohammed AA (2010) Nutritive evaluation of bambara groundnut (Vigna subterranea) pods, seeds and hulls as animal feeds. J Appl Sci Res 6: 383-386.

6. Hillocks RJ, Bennett C, Mponda OM (2011) Bambara nut: a review of utilisation, market potential and Crop improvement. Afr Crop Sci J. 20: $1-16$.

7. Bamishaiye OM, Adegbola JA, Bamishaiye EI (2011) Bambara groundnut: an Under-Utilized Nut in Africa. Adv Agricult Biotechnol 1: 60-72.

8. Ijarotimi OS, Oyewo MT, Oladeji BS (2009) Chemical, functional and sensory properties of roasted bambara groundnut (Vigna subterranean L. Verdc) and cooking banana (Musa spp., ABB genome) weaning diet. Afr J Food Sci 3: 139-146.

9. Okonkwo S, Opara M (2010) The analysis of bambara nut (Voandzeia subterranea (L.) thouars) for sustainability ion africa. Res J Appl Sci 5: 394-396.

10. Olanipekun BF, Otunola ET, Adejuyitan JA, Adeyanju JA (2012) Proximate and fatty acid composition of bambara groundnut (voandzeia subterranean 1. Thouars) as influenced by fermentation with a combination of Rhizopus oligosporus and R.nigricans. Trans J Sci Technol 2: 77-87.

11. Masood MI1, Qadir MI, Shirazi JH, Khan IU (2011) Beneficial effects of lactic acid bacteria on human beings. See comment in PubMed Commons below Crit Rev Microbiol 37: 91-98.

12. Onyango CA, Ochanda SO, Mwasaru MA, Ochieng JK, Mathooko FM, Kinyuru JN (2013) Effects of malting and fermentation on anti-nutrient reduction and protein digestibility of red sorghum, white sorghum and pearl millet. J Food Res 2: 41-49.

13. Akande KE, Fabiyi EF (2010) Effect of processing methods on some Antinutritional factors in Legumes seeds for poultry feeding. Int J Poultry Sci 9: 996-1001.

14. Kohajdová Z, Karovicová J (2007) Fermentation of cereals for specific purpose. J Food Nutr Res 46: 51-57.

15. Singh A, Yadav N, Sharma S (2012) Effect of fermentation on physicochemical properties $\&$ in vitro starch and protein digestibility of selected cereals. Int J Agric Food Sci 2: 66-70.

16. Ogodo, AC, Ugbogu OC, Onyeagba RA, Okereke HC, Agwaranze DI (2016) Dynamics of functional properties of maize flours fermented with lactic acid bacteria (LAB)-consortium isolated from cereals. FUW Trend Sci Technol J 1: 134-138.

17. AOAC (2005) Official Methods of Analysis, 18th ed. Association of Official Analytical Chemists. Gaithersburg, MD, USA.

18. Ojiako OA, Akubugwo EI (1997) An introductory approach to practical biochemistry. CRC Publications, Owerri.

19. Monjula S, John E (1991) Biochemical changes and in vitro protein digestibility of endosperm of germinating Dolichos lablab. J Sci Food Agric 55: 429-438.

20. Fawole MO, Oso BA (1988) Laboratory manual of microbiology. Spectrum Books Limited. Ibadan, Nigeria.

21. Okereke HC, Kanu IJ (2004) Identification and characterization of Microorganisms, pp. 95-110. In: Onyeagba, A. (Eds). Laboratory guide for Microbiology. Crystal Publishers. Okigwe, Nigeria.

22. Holt JG, Krieg NR, Sneath PH, Staley JT, Williams ST (1994) Bergey's manual of determinative bacteriology, 9th ed. Williams and Wilkins. Baltimore.

23. Bernett JA, Payne RW, Yarrow D (2000) Yeasts characteristics and identification, 3rd ed. Cambridge University Press. Cambridge.
24. Olalekan AJ, Bosede BF (2010) Comparative study on chemical composition and functional properties of three nigerian legumes (Jack Beans, Pigeon Pea and Cowpea). J Emerg Trends Eng Appl Sci 1: 89-95.

25. Adebowale OJ, Maliki K (2011) Effect of fermentation period on the chemical composition and functional properties of pigeon peas (Cajanus cajan) seed flour. Inter Food Res J 18: 1329-1333.

26. Adegbehingbe KT (2014) Microbiological analyses and nutrient composition of sorghum co-fermented with Lima bean seeds. Curr Res Microbiol Biotechnol 2: 431-437.

27. Maidala A, Doma UD, Egbo LM (2013) Effects of Different processing methods on the chemical composition and antinutritional factors of soybean [Glycine max (L.) Merrill]. Pak J Nutr 12: 1057-1060.

28. Mazahib AM, Nuha MO, Salawa IS, Babiker EE (2013) Some nutritional attributes of bambara groundnut as influenced by domestic processing. Inter Food Res J 20: 1165-117.

29. Ntuli V, Mekibib SB, Molebatsi N, Makotoko M, Chatanga P, Asita OA (2013) Microbial and physicochemical characterization of maize and wheat flour from a milling company, Lesotho. Int J Food Safety 15: 11-19.

30. Babalola RO, Giwa OE (2012) Effect of fermentation on nutritional and anti-nutritional properties of fermenting Soy beans and the antagonistic effect of the fermenting organism on selected pathogens. Inter Res J Microbiol 3: 333-338.

31. Chinma CE, Adewuyi O, Abu OJ (2009) Effect of germination on the chemical, functional and pasting properties of flours from brown and yellow varieties of tiger nut (Cyperus esculentus). Food Res Inter 42: 1104-1109.

32. El-Beltagi HES, Mohamed AA (2010) Variation in fatty acid composition, glucosinolate profile and some phytochemical contents in selected oil seed rape (Brassica napus L.) cultivars. Grasas Aceites 61: 143-150.

33. El-Beltagi HS, Mohamed AA, Mekki BB (2011) Differences in some constituents, enzymes activity and electrophoretic characterization of different rapeseed (Brassica napus L.) cultivars. Ann. Univ. OradeaFascicle Biol Tom 18: 39-46.

34. Afify AMR, Rashed MM, Ebtesam AM, El-Beltagi HS (2011) Effect of gamma radiation on protein profile, protein fraction and solubility of three oil seeds. Not Bot Horti Agrobo 39: 90-98.

35. Ojokoh A, Bello B (2014) Effect of fermentation on nutrient and antinutrient composition of millet (Pennisetum glaucum) and soyabean (Glycine max) blend flours. J Life Sci 8: 668-675.

36. Shobha D, Prasanna KMK, Puttaramanaik STA (2011) Effect of antioxidant on the shelf life of quality protein maize flour. Indian J Fund Appl Life Sci 1: 129-140.

37. Abdulsalami MS, Sheriff HB (2010) Effect of processing on the proximate composition and mineral content of bambara groundnut (Voandezeia subterranean). Bayero J Pure and Appl Sci 3: 188-190.

38. Ojokoh AO, Daramola MK, Oluoti OJ (2013) Effect of fermentation on nutrient and anti-nutrient composition of breadfruit (Treculia africana) and cowpea (Vigna unguiculata) blend flours. Afr J Agr Res 8: 3566-3570.

39. Ojokoh AO, Fayemi EO, Ocloo FCK, Alakija O (2014) Proximate composition, antinutritional contents and physicochemical properties of breadfruit (Treculia africana) and cowpea (Vigna unguiculata) flour blends fermented with Lactobacillus plantarum. Afr J Microbiol Res 8: 1352-1359.

40. Amankwah E, Barimah J, Acheampong R, Addai L, Nnaji C (2009) Effect of fermentation and malting on the viscosity of maize-soyabean weaning blends. Pak J Nutr 8: 1671-1675.

41. Ojokoh AO, Fayemi OE, Ocloo FCK, Nwokolo FI (2015) Effect of fermentation on proximate composition, physicochemical and microbial characteristics of pearl millet (Pennisetum glaucum (L.) R. Br.) and Acha (Digitaria exilis (Kippist) Stapf) flour blends. J Agr Biotechnol Sust Dev 7: 1-8.

42. Roger T, Léopold TN, Funtong MM (2015) Nutritional properties and antinutritional factors of corn paste (Kutukutu) fermented by different strains of lactic acid bacteria. Inter J Food Sci 1-14. 
Citation: Ogodo AC, Ugbogu OC, Onyeagba RA, Okereke HC (2018) Proximate Composition and In-vitro Starch/Protein Digestibility of Bambara Groundnut Flour Fermented with Lactic Acid Bacteria (LAB)-Consortium Isolated from Cereals. Ferment Technol 7: 148. doi: $10.4172 / 2167-7972.1000148$

Page 9 of 9

43. Hassan IAG, El Tinay AH (1995) Effects of fermentation on tannin content and in vitro protein and starch digestibility of two sorghum cultivars. Food Chem 53: 149-151.

44. Chen CC, Shih YC, Chiou PWS, Yu B (2010) Evaluating nutritional quality of single stage- and two stage-fermented soybean meal. AsianAust J Animal Sci 23: 598-606.

45. Mohiedeen IE, Tinay AHE, Elkhalya AEO, Babiker EE, Mallasiy LO (2010) Effect of fermentation on in vitro protein digestibility, protein fractions and amino acids composition of maize (Zea mays Linnaus) cultivars. Elec J Env Agri Food Chem 9: 838-847.

46. Olanipekun B, Adelekun O (2015) Nutritional and microbial attributes of soybean (Glycine max) during fermentation with Rhizopus oligosporus. Food Sci Qua. Manag 39: 111-118.

47. Ogunsakin OA, Banwo K, Ogunremi OR, Sanni AI (2015) Microbiological and physicochemical properties of sourdough bread from sorghum flour. Inter Food Res J. 22: 2610-2618.
48. Wakil SM, Daodu AA (2011) Physiological properties of a microbial community in spontaneous fermentation of maize (Zea mays) for ogi production. Inter Food Res J 2: 109-115.

49. Adegbehingbe KT (2013) Fermented Sprouted and Unsprouted Maize for Ogi Production. Inter J of Adv Res 1: 428-434.

50. Oyedeji O, Ogunbanwo ST, Onilude AA (2013) Predominant Lactic Acid Bacteria Involved in the Traditional Fermentation of Fufu and Ogi, Two Nigerian Fermented Food Products. Food Nutr Sci 4: 40-46.

51. Ventimiglia G1, Alfonzo A1, Galluzzo P2, Corona O1, Francesca N1, et al. (2015) Codominance of Lactobacillus plantarum and obligate heterofermentative lactic acid bacteria during sourdough fermentation. See comment in PubMed Commons below Food Microbiol 51: 57-68. 